\title{
Shallow circulation groundwater - the main type of water containing hazardous radon concentration
}

\author{
T. A. Przylibski \\ Wrocław University of Technology, Faculty of Geoengineering, Mining and Geology, Institute of Mining Engineering, \\ Division of Geology and Mineral Waters; Wybrzeże S. Wyspiańskiego 27, 50-370 Wrocław, Poland
}

Received: 31 January 2011 - Revised: 2 May 2011 - Accepted: 9 May 2011 - Published: 15 June 2011

\begin{abstract}
The main factors affecting the value of ${ }^{222} \mathrm{Rn}$ activity concentration in groundwater are the emanation coefficient of reservoir rocks $\left(K_{\mathrm{em}}\right)$, the content of parent ${ }^{226} \mathrm{Ra}$ in these rocks $(q)$, changes in the volume and flow velocity as well as the mixing of various groundwater components in the circulation system. The highest values of ${ }^{222} \mathrm{Rn}$ activity concentration are recorded in groundwaters flowing towards an intake through strongly cracked reservoir rocks undergoing weathering processes. Because of these facts, waters with hazardous radon concentration levels, i.e. containing more than $100 \mathrm{~Bq} \mathrm{dm}^{-3222} \mathrm{Rn}$, could be characterised in the way that follows. They are classified as radon waters, high-radon waters and extreme-radon waters. They belong to shallow circulation systems (at less than a few dozen metres below ground level) and are contemporary infiltration waters, i.e. their underground flow time ranges from several fortnights to a few decades. Because of this, these are usually poorly mineralised waters (often below $0.2-0.5 \mathrm{~g} \mathrm{dm}^{-3}$ ). Their resources are renewable, but also vulnerable to contamination.

Waters of this type are usually drawn from private intakes, supplying water to one or at most a few households. Due to an increased risk of developing lung tumours, radon should be removed from such waters when still in the intake. To achieve this aim, appropriate legislation should be introduced in many countries.
\end{abstract}

\section{Introduction}

Radon is a radioactive noble gas, highly soluble in water. Because of the half-life of its natural isotopes, it is practically only ${ }^{222} \mathrm{Rn}$ that plays an important part in the groundwater

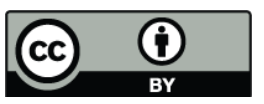

Correspondence to: T. A. Przylibski (tadeusz.przylibski@pwr.wroc.pl) and surface-water environment. The half-life of this radionuclide is 3.8224 days (Collé, 1995a, b). Thanks to this, ${ }^{222} \mathrm{Rn}$ isotope migrates with groundwaters at the distance enabling it to reach intakes and then - households. The value range of concentration activity of water-dissolved ${ }^{222} \mathrm{Rn}$ is very wide. The concentration of this gas in surface waters decreases very fast, as it is released into the atmosphere. Its concentration in the waters of streams and rivers oscillates from a fraction of a becquerel to a few dozen becquerels in a litre. In groundwaters, on the other hand, ${ }^{222} \mathrm{Rn}$ activity concentrations vary from a fraction of a becquerel to hundreds of thousand becquerels in a litre, i.e. within six orders of magnitude. This fact has become a basis for groundwater classification based on ${ }^{222} \mathrm{Rn}$ activity concentration (Table 1 ).

If radon waters, particularly high-radon or extreme-radon waters, are present in an intake supplying households, the residents are exposed to an extra effective dose from ionising radiation in the building. However it is not connected with consuming radon-containing water, but inhaling radon released from water, especially in bathrooms and kitchens while boiling (heating) water, particularly when it is sprayed - in a bath or a shower, or when doing the laundry or washing up (e.g. Bodansky et al., 1987; Cothern and Smith, 1987; Commission Recommendation, 2001; Kim et al., 2001; WHO, 2004; Swedjemark, 2004; López et al., 2004). The inhaled radon and particularly its short-lived daughters increase the risk of developing lung cancer (e.g. Bodansky et al., 1987; Cothern and Smith, 1987; WHO, 2004; Swedjemark, 2004; Krewski et al., 2005).

Aware of the risk connected with using radon-rich waters in households, some countries (e.g. USA, UK, Finland, Sweden, Norway, Russia, the Czech Republic or the Slovak Republic) have introduced limits of allowable ${ }^{222} \mathrm{Rn}$ activity concentration in consumable waters (reference levels), i.e. those which are supplied to households (Åkerblom, 1999). Appropriate guidelines in this area have also been adopted by international organisations (WHO,

Published by Copernicus Publications on behalf of the European Geosciences Union. 
Table 1. Groundwater classification based on ${ }^{222} \mathrm{Rn}$ content (according to Przylibski, 2005).

\begin{tabular}{ll}
\hline $\begin{array}{l}\text { Groundwater } \\
\text { name }\end{array}$ & $\begin{array}{l}{ }^{222} \mathrm{Rn} \text { activity } \\
\text { concentration } \\
\text { in groundwater } \\
{[\mathrm{Bq} \mathrm{dm}}\end{array}$ \\
& $<1$ \\
& $1-9.9(9)$ \\
\hline Radon-free water & $\left.\mathrm{kBq} \mathrm{m}^{-3}\right]$ \\
Radon-poor water & $10-99.9(9)$ \\
Low-radon water & $100-999.9(9)$ \\
Radon water & $1000-9999.9(9)$ \\
High-radon water & $\geq 10000$ \\
Extreme-radon water & \\
\hline
\end{tabular}

2004; Commission Recommendation, 2001). Any recommendations or legal regulations require monitoring ${ }^{222} \mathrm{Rn}$ activity concentration, and in the case of recording high values, they recommend or require removing radon from water while it is still in the intake, or they prohibit using it in households. The most reasonable limit requiring the monitoring of radon concentration in groundwater still present in an intake seems its activity concentration of $100 \mathrm{~Bq} \mathrm{dm}^{-3}$. If this level is significantly (several times) and repeatedly higher, then action should be taken to remove radon from water. It is best to keep ${ }^{222} \mathrm{Rn}$ activity concentration in intake water below the value of $100 \mathrm{~Bq} \mathrm{dm}^{-3}$ (WHO, 2004). Removing radon is absolutely necessary when ${ }^{222} \mathrm{Rn}$ activity concentration exceeds $1000 \mathrm{~Bq} \mathrm{dm}^{-3}$ (WHO, 2004; Commission Recommendation, 2001). The regulations introduced in Sweden do not allow using waters with ${ }^{222} \mathrm{Rn}$ activity concentration of over $1000 \mathrm{~Bq} \mathrm{dm}^{-3}$ at all (Åkerblom, 1999).

Studies, also those conducted by the author (Przylibski, 2000a, b, c, 2005, 2007; Przylibski and Żebrowski, 1996, 1999; Przylibski et al., 2001, 2002, 2004; Przylibski and Adamczyk-Lorenc, 2007) on the occurrence of radon, particularly ${ }^{222} \mathrm{Rn}$ isotope, in groundwater environment, have enabled obtaining a lot of information on the hydrogeochemistry of this radioactive gas (e.g. Rama and Moore, 1984; Fleischer, 1983, 1987; Greeman and Rose, 1996; Sun and Semkow, 1998; Luo et al., 2000; Wood et al., 2004; Barillon et al., 2005; Sasaki et al., 2004, 2005; Choubey et al., 2007). The knowledge of the origin, pattern and scale of radon migration in the groundwater environment enables us to define the type of waters involving a risk of the presence of high radon concentrations. Such waters should not be used in households or they should be de-radoned shortly before piping them to buildings.

The author's opinion is that it is now already possible to specify quite precisely and to characterise the type of groundwater which usually contains the highest and the most hazardous concentration of ${ }^{222} \mathrm{Rn}$.

\section{Facts, their interpretation and discussion}

In order to specify a particular type of groundwater which can be expected to contain the highest values of ${ }^{222} \mathrm{Rn}$ activity concentration, it is essential to characterise factors determining the amount of radon which could be dissolved in groundwater and the distance over which it is transported with this groundwater. According to the results of the author's own research (Przylibski, 2000a, c, 2005), the following factors should be considered as having the biggest influence on the concentration of ${ }^{222} \mathrm{Rn}$ activity in groundwaters:

- emanation coefficient of reservoir rocks $\left(K_{\mathrm{em}}\right)$,

- content of parent ${ }^{226} \mathrm{Ra}$ in these rocks $(q)$,

- changes in the volume and flow velocity as well as mixing of various groundwater components in a circulation system.

${ }^{222} \mathrm{Rn}$ activity concentration in groundwaters rises with the rise in the emanation coefficient of reservoir rocks and the rise in ${ }^{226} \mathrm{Ra}$ content in these rocks. Studies conducted by the author (Przylibski, 2005) in the area of the Sudetes (SW Poland) (Fig. 1) have demonstrated that distinctly increased values of ${ }^{222} \mathrm{Rn}$ activity concentration in groundwaters may be expected only when reservoir rocks exhibit increased values of both emanation coefficient and ${ }^{226} \mathrm{Ra}$ activity concentration. It has to be stressed here that clearly higher values of ${ }^{222} \mathrm{Rn}$ activity concentration were recorded only when the values of both $q$ and $K_{\mathrm{em}}$ were higher at the same time than $30 \mathrm{~Bq} \mathrm{~kg}^{-1}$ and 0.1 respectively (Fig. 2). Changes in flow velocity and the volume of water in a circulation system, as well as the process of mixing various groundwater components, may lead to mutually exclusive results, i.e. increasing or decreasing of ${ }^{222} \mathrm{Rn}$ activity concentration (Przylibski, 2005).

In order to calculate the $K_{\mathrm{em}}$ of reservoir rocks, the author used an equation (Przylibski, 2000c), later slightly modified and supplemented (Przylibski, 2005), which links the activity concentration of ${ }^{222} \mathrm{Rn}$ dissolved in groundwater $\left(c_{p \mathrm{Rn}}\right)$ with the emanation coefficient of its reservoir rocks $\left(K_{\mathrm{em}}\right)$, the activity concentration of parent ${ }^{226} \mathrm{Ra}$ in these rocks $(q)$, the physical properties of reservoir rocks affecting its permeability to waters and gases $\left(\rho_{\mathrm{s}}, n\right)$, as well as the activity concentration of ${ }^{226} \mathrm{Ra}^{2+}$ ions dissolved in this groundwater $\left(c_{p \mathrm{Ra} 0}\right)$ :

$c_{p \mathrm{Rn}}=\frac{(1-n) \cdot \rho_{s} \cdot q \cdot K_{\mathrm{em}}}{n}+c_{p \mathrm{Ra} 0}$

where:

$K_{\text {em }}$ - coefficient of ${ }^{222} \mathrm{Rn}$ emanation from reservoir rock to groundwater, [-],

$n$-effective porosity coefficient of reservoir rock, [-],

$c_{p \mathrm{Rn}}-{ }^{222} \mathrm{Rn}$ activity concentration in groundwater, $\left[\mathrm{Bq} \mathrm{m}^{-3}\right]$, 


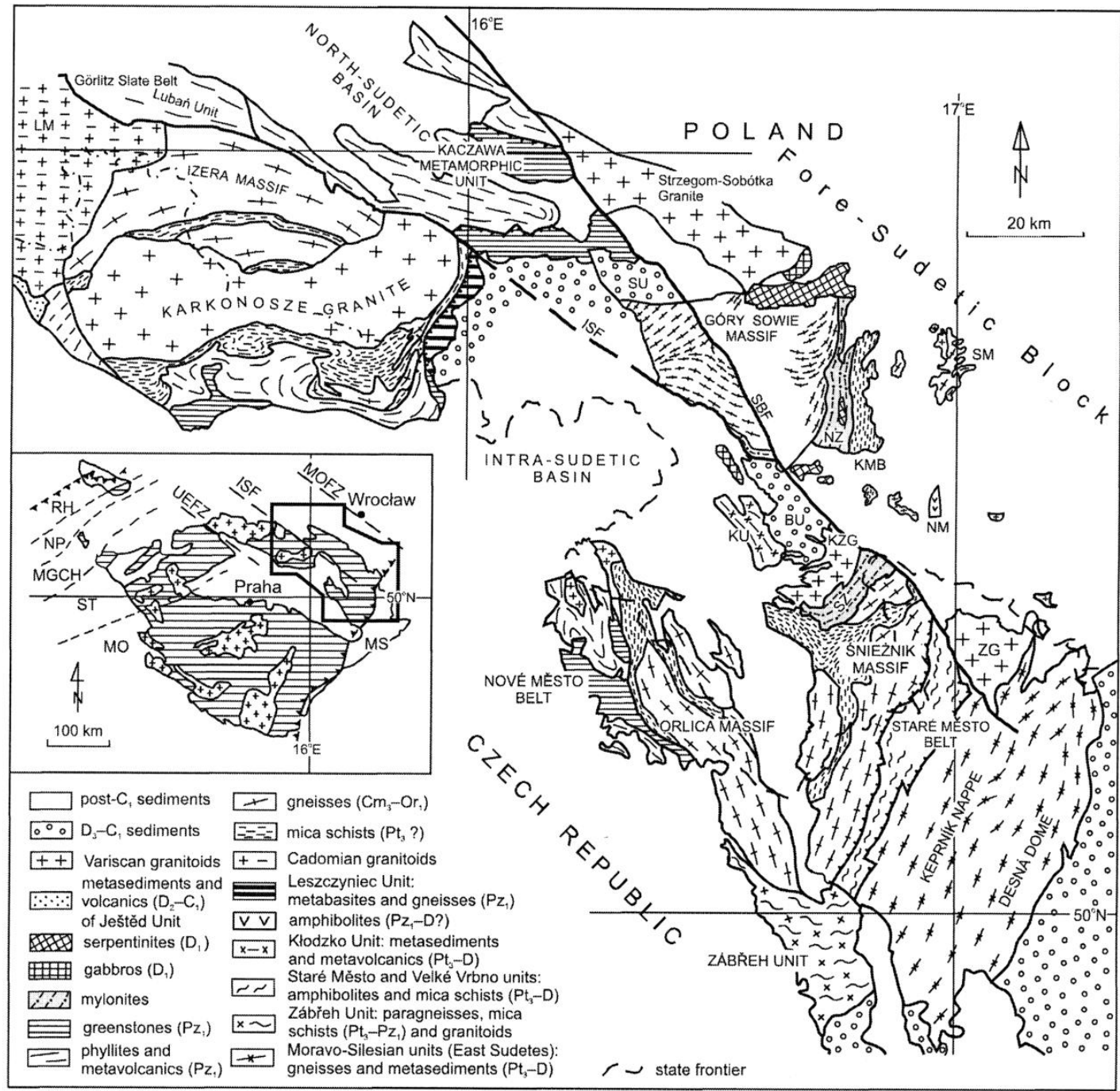

Fig. 1. Geological sketch map of the Sudetes (after Aleksandrowski et al., 1997). Explanations: BU - Bardo Sedimentary Unit, ISF Intra-Sudetic Fault, KMB - Kamieniec Metamorphic Belt, KU - Kłodzko Metamorphic Unit, KZG - Kłodzko-Złoty Stok Granite, LM Lusatian Massif, MGCH - Mid-German Crystalline High, MO - Moldanubian Zone, MOFZ - Middle Odra Fault Zone, MS - MoravoSilesian Zone, NM - Niedźwiedź Massif, NP - Northern Phyllite Zone, NZ - Niemcza Shear Zone, RH - Rhenohercynian Zone, SU Świebodzice Sedimentary Unit, SBF - Sudetic Boundary Fault, SM - Strzelin Massif, ST - Saxothuringian Zone, SZ - Skrzynka Shear Zone, UEFZ - Upper Elbe Fault Zone, ZG - Žulová Granite. Springs and intakes examined by the author were located within: Izera Massif, Karkonosze Granite, Intra-Sudetic Basin, Strzegom-Sobótka Granite, Kamieniec Metamorphic Belt, Śnieżnik Massif, Orlica Massif, Kaczawa Metamorphic Unit, Góry Sowie Massif.

$c_{p \mathrm{Ra} 0}-{ }^{226} \mathrm{Ra}$ activity concentration in groundwater, $\left[\mathrm{Bq} \mathrm{m}^{-3}\right]$, $\rho_{\mathrm{s}}$ - grain skeleton density, $\left[\mathrm{kg} \mathrm{m}^{-3}\right]$, $q-{ }^{226} \mathrm{Ra}$ content in reservoir rock, $\left[\mathrm{Bq} \mathrm{kg}^{-1}\right]$.

This equation expresses radioactive equilibrium in a closed system. One should also remember that it is not only the absolute value of the activity concentration of parent ${ }^{226} \mathrm{Ra}$ in these rocks that affects the activity concentration of radon dissolved in groundwater filling their pores and fissures. A vital factor is the distribution of ${ }^{226} \mathrm{Ra}$ atoms in rock. The nuclei of this radium isotope release far more
${ }^{222} \mathrm{Rn}$ atoms into the pore space (and fissures) if they are found in outer zones of mineral crystals or are contained in minerals present in the immediate neighbourhood of the surface of cracks and fissures or pores (Rama and Moore, 1984; Fleischer, 1983, 1987; Greeman and Rose, 1996; Sun and Semkow, 1998; Luo et al., 2000; Wood et al., 2004).

The coefficient of ${ }^{222} \mathrm{Rn}$ emanation from reservoir rocks to groundwaters mostly ranges between 0.01 to 0.1 , which means that from 1 to $10 \%$ of ${ }^{222} \mathrm{Rn}$ atoms formed as a result of the decay of ${ }^{226} \mathrm{Ra}$ nuclei found in the structures of minerals building these rocks or present on the surfaces of 
Table 2. Values of the parameters used for the $K_{\mathrm{em}}$ calculation and obtained from Eq. (1) $K_{\mathrm{em}}$ values for reservoir rocks supplying with groundwater selected intakes in the area of the Sudetes (according to Przylibski, 2005). Symbol explanations the same as for Eq. (1).

\begin{tabular}{|c|c|c|c|c|c|c|}
\hline \multirow{2}{*}{ Intake } & $c_{p \mathrm{Rn}}$ & $c_{p \mathrm{Ra} 0}$ & $q$ & $\rho_{\mathrm{s}}$ & $n$ & $\mathrm{~K}_{\mathrm{em}}$ \\
\hline & \multicolumn{2}{|c|}{$\left[\mathrm{Bq} \mathrm{m}^{-3}\right]$} & {$\left[\mathrm{Bq} \mathrm{kg}^{-1}\right]$} & {$\left[\mathrm{kg} \mathrm{m}^{-3}\right]$} & {$[-]$} & {$[-]$} \\
\hline \multicolumn{7}{|c|}{ IZERA MASSIF CZERNIAWA-ZDRÓJ } \\
\hline $\mathrm{nr} 4$ & 35100 & 780 & 38.8 & 2700 & 0.030 & 0.01 \\
\hline $\mathrm{P}-2$ & 15900 & 790 & 44.2 & 2650 & 0.035 & 0.005 \\
\hline \multicolumn{7}{|c|}{ IZERA MASSIF ŚWIERADÓW-ZDRÓJ } \\
\hline Górne A & 441100 & 46 & 73.3 & 2500 & 0.060 & 0.15 \\
\hline $1 \mathrm{~A}$ & 86800 & 525 & 73.3 & 2650 & 0.035 & 0.015 \\
\hline MCS-3 & 892400 & 68 & 55.5 & 2500 & 0.060 & 0.41 \\
\hline MCS-4 & 988800 & 67 & 55.5 & 2500 & 0.060 & 0.455 \\
\hline MCS-5 & 1517000 & 44 & 55.5 & 2500 & 0.060 & 0.70 \\
\hline MCS-6 & 668000 & 36 & 55.5 & 2500 & 0.060 & 0.31 \\
\hline \multicolumn{7}{|c|}{ INTRA-SUDETIC BASIN SZCZAWNO-ZDRÓJ } \\
\hline Marta & 215700 & 706 & 29.5 & 2450 & 0.100 & 0.33 \\
\hline Młynarz & 32300 & 77 & 26.5 & 2450 & 0.100 & 0.055 \\
\hline \multicolumn{7}{|c|}{ INTRA-SUDETIC BASIN POLANICA-ZDRÓJ } \\
\hline P-300 & 5100 & 1009 & 14.2 & 2450 & 0.150 & 0.02 \\
\hline Pieniawa Józefa II & 22000 & 120 & 14.2 & 2400 & 0.180 & 0.14 \\
\hline Wielka Pieniawa & 16800 & 270 & 14.2 & 2400 & 0.180 & 0.105 \\
\hline \multicolumn{7}{|c|}{ INTRA-SUDETIC BASIN GORZANÓW } \\
\hline nr 5 & 34600 & 38 & 20 & 2400 & 0.210 & 0.19 \\
\hline nr 6 & 4900 & 84 & 20 & 2400 & 0.210 & 0.03 \\
\hline $\mathrm{nr} 7 \mathrm{M}$ & 17000 & 40 & 20 & 2400 & 0.190 & 0.08 \\
\hline \multicolumn{7}{|c|}{ KARKONOSZE GRANITE CIEPLICE ŚLĄSKIE-ZDRÓJ } \\
\hline nr 1 Marysieńka & 11000 & 19 & 63.8 & 2550 & 0.035 & 0.005 \\
\hline nr 2 Sobieski & 140300 & 24 & 63.8 & 2500 & 0.040 & 0.04 \\
\hline \multicolumn{7}{|c|}{ ŚNIEŻNIK MASSIF LĄDEK-ZDRÓJ } \\
\hline Chrobry & 137100 & 10 & 47.3 & 2500 & 0.060 & 0.075 \\
\hline Jerzy & 1109000 & 88 & 47.3 & 2450 & 0.065 & 0.665 \\
\hline L-2 (Zdzisław) & 117100 & 12 & 47.3 & 2600 & 0.030 & 0.03 \\
\hline Skłodowska-Curie & 329500 & 26 & 47.3 & 2500 & 0.060 & 0.18 \\
\hline Wojciech & 218600 & 15 & 47.3 & 2500 & 0.060 & 0.12 \\
\hline
\end{tabular}

pores, cracks and fissures are dissolved in groundwaters (Table 2). In the zones of intensive weathering, affecting the rise in crack density and rock porosity, as well as zones disturbed by intensive brittle tectonic deformations, $K_{\mathrm{em}}$ values can reach 0.3 or even 0.7 (Table 2). Theoretical studies demonstrate that in specific conditions, the emanation coefficient can reach values of up to 0.75 (Sasaki et al., 2005).

The process of mixing various groundwater components may lead to changes in ${ }^{222} \mathrm{Rn}$ activity concentration in water flowing to an intake. Radon content usually increases with a rise in the proportion of a water component flowing through a zone of cracked, weathered and ${ }^{226} \mathrm{Ra}$-rich reservoir rocks in the groundwater mixture flowing out of them. This is usually the infiltration component of shallow circulation (Przylibski, 2005).

The above facts should be also supplemented with the results of the author's research into the occurrence of parent ${ }^{226} \mathrm{Ra}^{2+}$ ions in groundwaters. Theoretically, they could be also an additional source of ${ }^{222} \mathrm{Rn}$ atoms dissolved in groundwaters. Measurements performed in over 100 intakes in SW Poland (the Sudetes) have clearly demonstrated that in the vast majority of groundwaters (85\% of studied intakes), at 


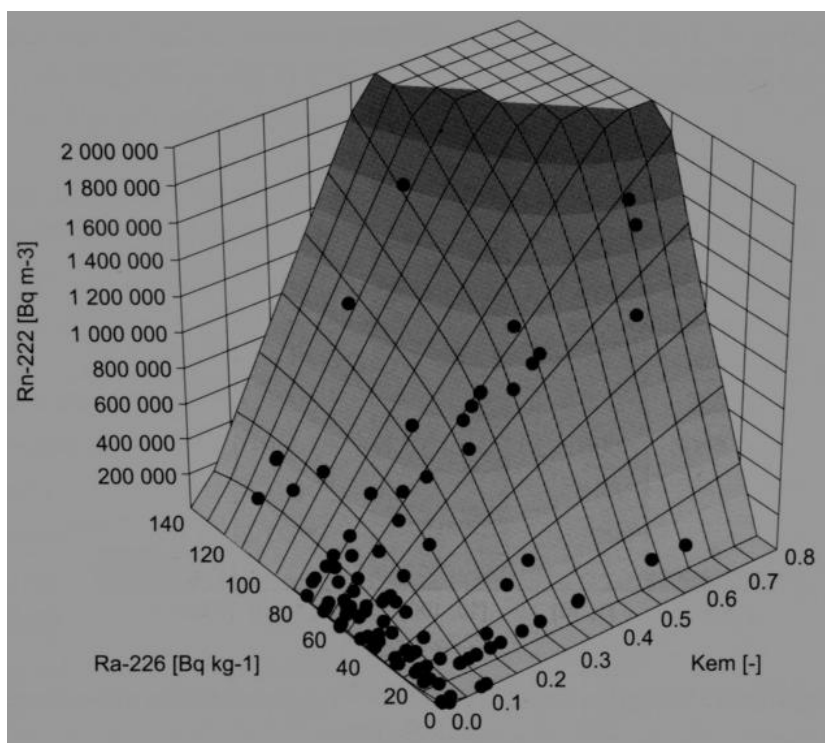

Fig. 2. Correlation between mean ${ }^{222} \mathrm{Rn}$ activity concentration in the groundwater and mean content of ${ }^{226} \mathrm{Ra}$ in its reservoir rock $(q)$ and the value of the emanation coefficient $\left(K_{\mathrm{em}}\right)$ of this rock for 111 selected groundwater intakes in the area of the Sudetes (SW Poland) (according to Przylibski, 2005).

least $99 \%$ of ${ }^{222} \mathrm{Rn}$ atoms originate in reservoir rocks, while hardly $1 \%$ are formed as a result of radioactive transformation of ${ }^{226} \mathrm{Ra}^{2+}$ ions dissolved in these waters (Przylibski, 2005; Przylibski and Żebrowski, 1996, 1999; Przylibski et al., 2001, 2002) (Table 3).

The last important issue is the distance at which ${ }^{222} \mathrm{Rn}$ migrates with groundwaters. This distance depends chiefly on the flow velocity of water and is mainly determined by the kind of medium i.e. the type of reservoir rock. The lowest flow velocity is characteristic of a porous medium (permeable due to the effective porosity), higher - of a fissured one, and the highest - of large karst systems. Its changes range from fractions of a metre through dozens to hundreds of metres per 24 h (Bear, 1972, 1979; Zuber et al., 1995). The distance of radon transport from its place of formation as a result of nuclear transformation alpha of ${ }^{226} \mathrm{Ra}$ nucleus in mineral structure is also strictly limited by the lifetime of the ${ }^{222} \mathrm{Rn}$ isotope. If we agree that ${ }^{222} \mathrm{Rn}$ atoms can be transported for at most 38 days, i.e. for the time $10 \mathrm{~T}_{1 / 2}$, while only $0.1 \%$ remain from the initial number of nuclei, then the distance of radon transport comes from a few metres to a few hundred metres, except that in karst systems it could be even higher (Przylibski, 2000a, 2005; Przylibski et al., 2001) (Table 4). As a rule then, what should be emphasized is that radon reaches a groundwater intake from its immediate neighbourhood, travelling together with water, from a few to a few hundred metres at the time no longer than 38 days. By far the highest number of ${ }^{222} \mathrm{Rn}$ atoms are released into water very close to the intake - usually at the distance of a few meters from the intake. ${ }^{222} \mathrm{Rn}$ atoms dissolved at a further distance (earlier) undergo radioactive decay before the groundwater reaches the intake. Therefore, what has to be stressed is that its activity concentration in water in the intake is determined by the geology and mineral (and chemical) composition of the rocks in the immediate vicinity of the well, borehole or spring.

Radon content in surface water depends, among other factors, on partial pressure of this gas over water - in the atmosphere. As it is very small in the atmosphere $-{ }^{222} \mathrm{Rn}$ activity concentration in the air over mainland, at the height of $1-$ $2 \mathrm{~m}$ over the ground is usually from a few to about a dozen $\mathrm{Bq} \mathrm{m}^{-3}$ (Cothern and Smith, 1987; Nevissi and Bodansky, 1987; Jagielak et al., 1998; Kataoka et al., 2003; Sesana et al., 2003; Nagaraja et al., 2003 etc.), hence also radon concentration in surface water normally does not exceed several or at most a few dozen $\mathrm{Bq} \mathrm{dm}^{-3}$. The concentration depends chiefly on the type of rocks building the bed and the sides of a stream or river (Przylibski, 2005). Therefore, if groundwater in an intake (well, spring or borehole) comes in contact with the atmosphere, then ${ }^{222} \mathrm{Rn}$ activity concentration in this water decreases significantly and, as a rule, does not pose any threat at all. However, in professionally constructed groundwater intakes, water does not usually have contact with the atmosphere and it is supplied to a building (private intake) or a pipe network (public intake) with almost all ${ }^{222} \mathrm{Rn}$ atoms that have reached the intake with groundwater. Only a small number of radon atoms undergo natural radioactive decay and do not reach consumers, unless the pipeline and reservoir network is very large, like e.g. in big cities.

The above facts indicate that the highest concentrations of radon could be expected in groundwaters drawn from ${ }^{226} \mathrm{Ra}-$ enriched reservoir rocks, which are characterised by high emanation coefficient. ${ }^{222} \mathrm{Rn}$ atoms reach an intake from its immediate neighbourhood, and if the groundwater in the intake does not come in contact with the atmospheric air, a large number of radon atoms may then reach households.

The highest emanation coefficient is characteristic of reservoir rocks which have a dense crack network or/and high porosity and are vulnerably exposed to weathering processes, both physical and chemical. Physical weathering plays an important part in rock fragmentation, as it results in increasing the volume of pores and fissures which enable groundwaters to circulate freely. Chemical weathering, on the other hand, besides further fragmentation of mineral components, enables the precipitation of secondary minerals (chemical compounds) containing ${ }^{226} \mathrm{Ra}$ atoms in pores and fissures. In such a case, the process of ${ }^{222} \mathrm{Rn}$ atom emanation into groundwaters filling pores and fissures is additionally intensified - the emanation coefficient is significantly higher. The crack network is much denser, which also contributes to increasing the emanation coefficient when reservoir rocks lie in tectonic deformation zones - close to faults, tectonic thrusts, etc. The role of tectonic deformations in this context has been emphasized in many publications (e.g. Choubey et 
Table 3. Percentage part of ${ }^{222} \mathrm{Rn}$ atoms produced as a result of the decay of ${ }^{226} \mathrm{Ra}^{2+}$ ions dissolved in groundwater in total ${ }^{222} \mathrm{Rn}$ atoms dissolved in groundwater of selected intakes in the Sudetes. These values are presented together with the information on ${ }^{222} \mathrm{Rn}$ and ${ }^{226} \mathrm{Ra}$ activity concentrations and TDS values for these groundwaters (according to Przylibski, 2005).

\begin{tabular}{|c|c|c|c|c|}
\hline \multirow{2}{*}{ Intake } & TDS & ${ }^{222} \mathrm{Rn}$ & ${ }^{226} \mathrm{Ra}$ & ${ }^{226} \mathrm{Ra} /{ }^{222} \mathrm{Rn}$ \\
\hline & {$\left[\mathrm{g} \mathrm{m}^{-3}\right]$} & \multicolumn{2}{|c|}{$\left[\mathrm{Bq} \mathrm{m}^{-3}\right]$} & {$[\%]$} \\
\hline \multicolumn{5}{|c|}{ IZERA MASSIF CZERNIAWA-ZDRÓJ } \\
\hline $\mathrm{nr} 4$ & 2802 & 35100 & 780 & 2.22 \\
\hline $\mathrm{P}-2$ & 2125 & 15900 & 790 & 4.97 \\
\hline \multicolumn{5}{|c|}{ IZERA MASSIF S̀WIERADÓW-ZDRÓJ } \\
\hline Górne A & 289 & 441100 & 46 & 0.01 \\
\hline $1 \mathrm{~A}$ & 683 & 86800 & 525 & 0.61 \\
\hline $2 \mathrm{P}$ & 1984 & 21000 & 778 & 3.71 \\
\hline \multicolumn{5}{|c|}{ INTRA-SUDETIC BASIN SZCZAWNO-ZDRÓJ } \\
\hline Marta & 2319 & 215700 & 706 & 0.33 \\
\hline Młynarz & 2291 & 32300 & 77 & 0.24 \\
\hline Mieszko & 3025 & 31200 & 135 & 0.43 \\
\hline Mieszko-14 & 701 & 9600 & 53 & 0.55 \\
\hline \multicolumn{5}{|c|}{ INTRA-SUDETIC BASIN KUDOWA-ZDRÓJ } \\
\hline K-200 & 3456 & 7200 & 640 & 8.89 \\
\hline nr 2 Moniuszko & 3436 & 5500 & 110 & 2.00 \\
\hline nr 3 Nowy Marchlewski & 1699 & 59200 & 70 & 0.12 \\
\hline Górne & 2367 & 18700 & 160 & 0.86 \\
\hline \multicolumn{5}{|c|}{ S̀NIEŻNIK MASSIF LĄDEK-ZDRÓJ } \\
\hline Chrobry & 201 & 137100 & 10 & 0.007 \\
\hline Dąbrówka & 199 & 127700 & 11 & 0.009 \\
\hline Jerzy & 188 & 1109000 & 88 & 0.008 \\
\hline L-2 (Zdzisław) & 208 & 117100 & 12 & 0.010 \\
\hline Skłodowska-Curie & 199 & 329500 & 26 & 0.008 \\
\hline Wojciech & 202 & 218600 & 15 & 0.007 \\
\hline \multicolumn{5}{|c|}{ ORLICA MASSIF DŁUGOPOLE-ZDRÓJ } \\
\hline Emilia & 910 & 108500 & 90 & 0.08 \\
\hline Renata & 1218 & 68800 & 100 & 0.15 \\
\hline Kazimierz & 937 & 65300 & 120 & 0.18 \\
\hline
\end{tabular}

al., 2007; Przylibski, 2005, 2007; Przylibski et al., 2001). Such zones are usually also perfect paths for groundwater migration.

The above characteristics of reservoir rocks of groundwaters containing increased concentrations of radon (radon waters, high-radon waters and extreme-radon waters) enable characterizing their general type. These are waters of shallow circulation (up to several dozen metres below ground level) and contemporary infiltration, i.e. with underground flow time ranging from several days to a few or a few dozen years. Owing to their underground flow time, these are usually also poorly-mineralised waters (total dissolved solids TDS is usually $<0.2-0.5 \mathrm{~g} \mathrm{dm}^{-3}$ ) (Fig. 3). Their resources are renewable, however, due to their small depth, short underground flow time and contact with the surface of the lithosphere and the atmosphere, these waters are also vulnerable to contamination.

The above characteristics of groundwaters which could potentially be radon waters, high-radon waters or extremeradon waters, result mostly from recognising the influence of the emanation coefficient of reservoir rocks on ${ }^{222} \mathrm{Rn}$ activity concentration in groundwaters. Also, taking into consideration the influence of ${ }^{226} \mathrm{Ra}$ content in reservoir rocks, one should conclude that groundwaters flowing from ${ }^{226} \mathrm{Ra}-$ enriched rocks will obviously exhibit an increased concentration of ${ }^{222} \mathrm{Rn}$. However, for the same reservoir rocks, waters 
Table 4. The distance of ${ }^{222} \mathrm{Rn}$ atoms transport with groundwater to the intake (L) and the discharge of the intake (Q) for selected wells and boreholes in the Sudetes (according to Przylibski, 2005).

\begin{tabular}{|c|c|c|}
\hline \multirow{2}{*}{ Intake } & Q & $\mathrm{L}$ \\
\hline & {$\left[\mathrm{m}^{3} \mathrm{~d}^{-1}\right]$} & {$[\mathrm{m}]$} \\
\hline \multicolumn{3}{|c|}{ IZERA MASSIF ŚWIERADÓW-ZDRÓJ } \\
\hline $1 \mathrm{~A}$ & 19.9 & 16 \\
\hline $2 \mathrm{P}$ & 5.3 & 6 \\
\hline \multicolumn{3}{|c|}{ INTRA-SUDETIC BASIN SZCZAWNO-ZDRÓJ } \\
\hline Marta & 1.0 & 3 \\
\hline Mieszko & 8.0 & 8 \\
\hline \multicolumn{3}{|c|}{ INTRA-SUDETIC BASIN POLANICA-ZDRÓJ } \\
\hline Wielka Pieniawa & 446.4 & 32 \\
\hline \multicolumn{3}{|c|}{ INTRA-SUDETIC BASIN GORZANÓW } \\
\hline $\operatorname{nr} 5$ & 1157.0 & 13 \\
\hline nr 1 (Złota Kaczka) & 388.0 & 63 \\
\hline \multicolumn{3}{|c|}{ KARKONOSZE GRANITE CIEPLICE ŚLĄSKIE-ZDRÓJ } \\
\hline nr 2 Sobieski & 4.5 & 10 \\
\hline nr 4 Nowe & 89.0 & 43 \\
\hline \multicolumn{3}{|c|}{ KARKONOSZE GRANITE SZKLARSKA PORĘBA } \\
\hline $\mathrm{nr} 1$ & 89.0 & 38 \\
\hline nr 6 & 29.0 & 22 \\
\hline \multicolumn{3}{|c|}{ KAMIENIEC METAMORPHIC BELT PRZERZECZYN-ZDRÓ. } \\
\hline $\mathrm{nr} 2$ & 89.0 & 57 \\
\hline nr 9 & 89.0 & 16 \\
\hline \multicolumn{3}{|c|}{ ŚNIEŻNIK MASSIF LĄDEK-ZDRÓJ } \\
\hline Chrobry & 55.0 & 19 \\
\hline Jerzy & 380.0 & 49 \\
\hline \multicolumn{3}{|c|}{ ŚNIEŻNIK MASSIF KAMIENICA } \\
\hline Śnieżnik adit & 1930.0 & 110 \\
\hline K6 & 360.0 & 67 \\
\hline \multicolumn{3}{|c|}{ ŚNIEŻNIK MASSIF KLETNO } \\
\hline Kletno I spring & 2720.0 & $271 *$ \\
\hline Romanowskie 1 spring & 1700.0 & $214^{*}$ \\
\hline
\end{tabular}

* karst groundwater

with the highest ${ }^{222} \mathrm{Rn}$ activity concentration will circulate in and flow out of zones with an increased emanation coefficient, i.e. from cracked and weathered rocks in the nearsurface part of the lithosphere.

The practical relevance of the above discussion and the ensuing conclusions has been confirmed by the author's study of over 100 groundwater intakes in the area of the Sudetes (SW Poland) (Przylibski, 2005). It demonstrated that the highest emanation coefficient is characteristic of rocks lying in the weathering zone, to the depth of $30-50 \mathrm{~m}$ below ground level. The highest values of ${ }^{222} \mathrm{Rn}$ activity con-

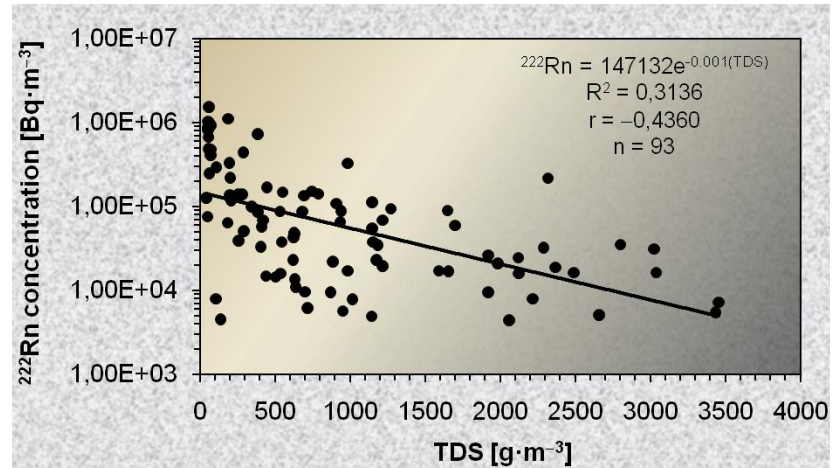

Fig. 3. Correlation between ${ }^{222} \mathrm{Rn}$ activity concentration in groundwater and the mineralization (Total Dissolved Solids) of the groundwater for the 93 selected intakes and springs of the Sudetes (SW Poland) (according to Przylibski, 2005).

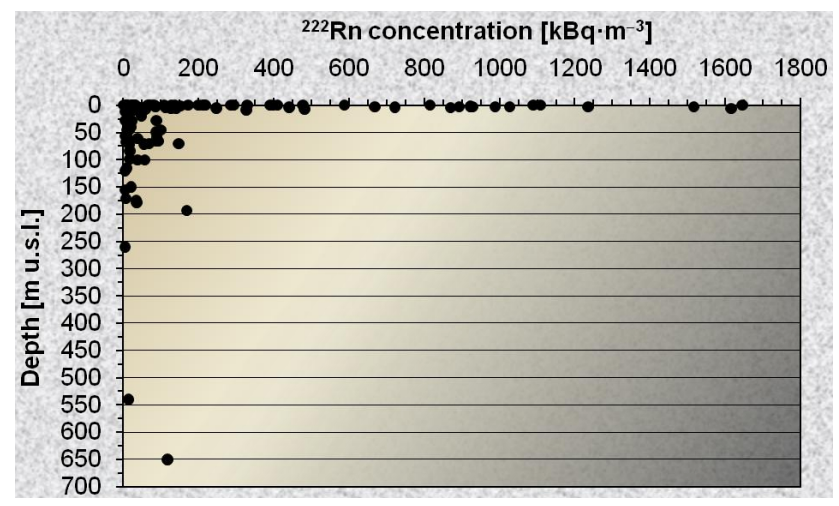

Fig. 4. Correlation between ${ }^{222} \mathrm{Rn}$ activity concentration and the depth of groundwater intake for the 111 selected intakes from the area of the Sudetes (SW Poland) (according to Przylibski, 2005).

centration are recorded in groundwaters drawn from these rocks. They increase with the rise in ${ }^{226} \mathrm{Ra}$ content in reservoir rocks. At large depths, even a high content of ${ }^{226} \mathrm{Ra}$ in reservoir rock does not cause the formation of high values of ${ }^{222} \mathrm{Rn}$ activity concentration in the groundwater flowing through it (Fig. 4). This regularity has been presented before for a smaller number of analysed groundwaters (Ciężkowski and Przylibski, 1997).

It is also noteworthy that the groundwaters that can potentially contain dangerously high $\left(\geq 100 \mathrm{~Bq} \mathrm{dm}^{-3}\right)$ radon concentrations, i.e. radon waters, high-radon waters and extreme-radon waters, are all groundwaters whose resources are the easiest to be drawn for household use and for consumption. They are often the main source of water supply for individual households and, through private intakes, they often supply one or a few families (houses). More rarely, such groundwaters are drawn from public intakes. Deradoning of such waters in an intake is relatively simple and does not require installing any complicated equipment, so the cost of this process is also low compared to the cost of 
a building or even the cost of a water intake itself. Having in mind the risk of developing a lung tumour related to household use of waters containing increased radon concentration, bearing the expenses of de-radoning water in an intake seems reasonable and well-grounded.

\section{Conclusions}

Waters that can potentially contain the highest $\left(\geq 100 \mathrm{~Bq} \mathrm{dm}^{-3}\right)$ hazardous contents of dissolved radon are groundwaters of shallow circulation (to the depth of several dozen metres below ground level) and contemporary infiltration, i.e. with underground flow time of a few days or a few fortnights and a few years to a few decades. In terms of underground flow time, these are mostly also poorly mineralised waters (TDS $<0.2-0.5 \mathrm{~g} \mathrm{dm}^{-3}$ ). Their resources are renewable, but due to the small depth and short underground flow time, as well as contact with the surface of the litosphere and the atmosphere, these waters are also vulnerable to contamination. Based on the content of ${ }^{222} \mathrm{Rn}$ dissolved in them, these waters should be classified as radon waters, high-radon waters and extreme-radon waters.

Such waters are usually drawn from private intakes and are intended for consumption and household use, usually in one or at most a few buildings. More rarely, such waters are drawn from public intakes. This is why these are largely owners of private groundwater intakes who are the most exposed to radon exhalation from waters used in households, and consequently - to obtaining a higher dose of ionising radioactivity from radon and its radioactive daughters. This situation is particularly disadvantageous, as the cost of removing radon from waters drawn from several or several dozen intakes in one town or village is higher than in the cost of de-radoning water in one big public intake.

In conclusion, it seems necessary to take practical, and in some countries also legislative steps, modelled on regulations introduced earlier in some other countries. They should be aimed at introducing compulsory measurements of ${ }^{222} \mathrm{Rn}$ activity concentration chiefly in groundwaters of shallow circulation and contemporary infiltration, especially those drawn from small private intakes - individually dug wells or shallow drilled wells (up to several dozen metres below ground level). These waters, in any circumstances, will contain locally (in an area with the same geological structure - within one lithostratigraphic unit) the highest radon concentration. Using these water resources (radon waters, high-radon waters and extreme-radon waters) in many cases probably requires and will require removing at least some radon from groundwater when still in the intake, i.e. before supplying it to the piping network, or directly to a building, in case of a private intake.
Acknowledgements. The author wishes to thank the handling Editor, Frederic Perrier for valuable comments leading to new ideas and research projects. The comments of Agemar Siehl and two other anonymous referees were also helpful during manuscript revision. Publication of this article was possible thanks to the funds of the internal research project no. 343172 of the Wrocław University of Technology.

Edited by: F. Perrier

Reviewed by: A. Siehl and two other anonymous referees

\section{References}

Aleksandrowski, P., Kryza, R., Mazur, S., and Żaba, J.: Kinematic data on major Variscan strike-slip faults and shear zones in the Polish Sudetes, northeast Bohemian Massif, Geol. Mag., 133, 727-739, 1997.

Åkerblom, G: Radon legislation and national guidelines, European Research into Radon in Construction Concerted Action (ERRICCA) Report F14P-CT96-0064(DG12-WSMN), 18-20, 1999.

Barillon, R., Özgümüs, A., and Chambaudet, A.: Direct recoil radon emanation from crystalline phases. Influence of moisture content. Geochim. Cosmochim. Ac., 69, 11, 2735-2744, 2005.

Bear, J.: Dynamics of fluids in porous media, Elsevier, New York, 1972.

Bear, J.: Hydraulics of groundwater, McGraw-Hill, New York, 1979.

Bodansky, D., Robkin, M. A., and Stadler, D. R.: Indoor radon end its hazards, University of Washington Press, Seattle and London, 1987.

Choubey, V. M., Mukherjee, P. K., Bajwa, B. S., and Walia, W.: Geological and tectonic influence on water-soil-radon relationship in Mandi-Manali area, Himachal Himalaya, Environ. Geol., 52, 1163-1171, 2007.

Ciężkowski, W. and Przylibski, T. A.: Radon in waters from health resorts of the Sudety Mts. (SW Poland), Appl. Radiat. Isotopes, 48, 6, 855-856, 1997.

Collé, R.: A precise determination of the ${ }^{222} \mathrm{Rn}$ half-life by $4 \pi-\alpha \beta$ liquid scintillation measurements, Radioactivity \& Radiochemistry, 6, 1, 16-29, 1995a.

Collé, R.: Critically evaluated half-life for ${ }^{222} \mathrm{Rn}$ radioactive decay and associated uncertainties, Radioactivity \& Radiochemistry, 6, 1, 30-40, 1995b.

Commission Recommendation of 20 December 2001 on the protection of the public against exposure to radon in drinking water supplies, 2001/928/Euratom, 2001.

Cothern, C. R. and Smith, J. E. Jr.: Environmental Radon. Plenum Press, New York, 1987.

Fleischer, R. L.: Theory of alpha recoil effects on radon release and isotopic disequilibrium, Geochim. Cosmochim. Ac., 47, 779784, 1983.

Fleischer, R. L.: Moisture and ${ }^{222}$ Rn emanation, Health Phys., 52, 6, 797-799, 1987.

Greeman, D. J. and Rose, A. W.: Factors controlling the emanation of radon and thoron in soils of the eastern U.S.A., Chem. Geol., 129, 1-14, 1996.

Jagielak, J., Biernacka, M., Henschke, J., and Sosińska, A.: Radiological atlas of Poland 1997, Biblioteka 
Monitoringu Środowiska, Państwowa Inspekcja Ochrony Środowiska, Centralne Laboratorium Ochrony Radiologicznej, Państwowa Agencja Atomistyki, Warszawa, 1998.

Kataoka, T., Yunoki, E., Shimizu, M., Mori, T., Tsukamoto, O., Takahashi, S., Fudeyasu, H., Ohashi, Y., Sahashi, K., Maitani, T., Miyashita, K., Iwata, T., Sasaki, T., Fujikawa, Y., Kudo, A., and Shaw, R. H.: Concentrations of ${ }^{222} \mathrm{Rn}$, its short-lived daughters and ${ }^{212} \mathrm{~Pb}$ and their ratios under complex atmospheric conditions and topography, Bound.-Lay. Meteorol., 107, 219-249, 2003.

Kim, E., Little, J. C., Chiu, N., and Chiu, A.: Inhalation exposure to volatile chemicals in drinking water, J. Environ Sci. Heal. C., C19, 2, 387-413, 2001.

Krewski, D., Lubin, J. H., Zielinski, J. M., Alavanja, M., Catalan, V. S., Field, R. W., Klotz, J. B., Létourneau, E. G., Lynch, C. F., Lyon, J. I., Sandler, D. P., Schoenberg, J. B., Steck, D. J., Stolwijk, J. A., Weinberg, C., and Wilcox, H. B.: Residential radon and risk of lung cancer, A combined analysis of 7 North American case-control studies, Epidemiology, 16, 2, 137-145, 2005.

López, M. G., Sánchez, A. M., and Escobar, V. G.: Estimates of the dose due to ${ }^{222} \mathrm{Rn}$ concentrations in water, Radiat. Prot. Dosim., 111, 1, 3-7, 2004.

Luo, S., Ku, T.-L., Roback, R., Murrell, M., and McLing, T. L.: Insitu radionuclide transport and preferential groundwater flows at INEEL (Idaho): Decay-series disequilibrium studies, Geochim. Cosmochim. Ac., 64, 5, 867-881, 2000.

Nagaraja, K., Prasad, B. S. N., Madhava, M. S., and Paramesh, L.: Concentration of radon and its progeny near the surface of the earth at a continental station Pune (18 N, 74 E), Indian J. Pure Ap. Mat. Phy., 41, 562-569, 2003.

Nevissi, A. E. and Bodansky, D.: Radon sources and levels in the outside environment, in: Chapter 4 from: Indoor radon end its hazards, edited by: Bodansky, D., Robkin, M. A., Stadler, D. R., University of Washington Press, Seattle and London, 42-50, 1987.

Przylibski, T. A.: Size estimation and protection of the areas supplying radon to groundwater intakes, Archiv. Environ. Prot., 26, 1, 55-71, 2000a.

Przylibski, T. A.: ${ }^{222} \mathrm{Rn}$ concentration changes in medicinal groundwaters of Lądek Zdrój (Sudety Mountains, SW Poland), J. Environ. Radioactiv., 48, 3, 327-347, 2000b.

Przylibski, T. A.: Estimating the radon emanation coefficient from crystalline rocks into groundwater, Appl. Radiat. Isotopes, 53, 3, 473-479, 2000c.

Przylibski, T. A.: Radon, Specific component of medicinal waters in the Sudety Mountains, Oficyna Wydawnicza Politechniki Wrocławskiej, Wrocław, 2005 (in Polish).

Przylibski, T. A.: Radon as a natural radioactive tracer for studying crystalline rock aquifers - a few usage concepts, Acta Universitatis Wratislaviensis, 3041, Hydrogeologia, 125-142, 2007.
Przylibski, T. A. and Adamczyk-Lorenc, A.: Selected problems of radon groundwaters presence in the Polish part of the Sudetes, Acta Universitatis Wratislaviensis, 3041, Hydrogeologia, 115124, 2007.

Przylibski, T. A. and Żebrowski A.: Origin of radon in medicinal waters of Świeradów Zdrój. Nukleonika, 41, 4, 109-116, 1996.

Przylibski, T. A., and Żebrowski, A.: Origin of radon in medicinal waters of Lądek Zdrój (Sudety Mountains, SW Poland), J. Environ. Radioactiv., 46, 121-129, 1999.

Przylibski, T. A., Mroczkowski K., Żebrowski A., and Filbier, P.: Radon-222 in medicinal groundwaters of Szczawno Zdrój (Sudety Mountains, SW Poland), Environ. Geol., 40, 4/5, 429439, 2001.

Przylibski, T. A., Kozłowska B., Dorda J., and Kiełczawa B.: Radon-222 and ${ }^{226} \mathrm{Ra}$ concentrations in mineralized groundwaters of Gorzanów (Kłodzko Basin, Sudeten Mountains, SW Poland), J. Radioanal. Nucl. Chem., 253, 1, 11-19, 2002.

Przylibski, T. A., Mamont-Cieśla, K., Kusyk, M., Dorda, J., and Kozłowska, B.: Radon concentrations in groundwaters of the Polish part of the Sudety Mountains (SW Poland), J. Environ. Radioactiv., 75, 2, 193-209, 2004.

Rama and Moore, W. S.: Mechanism of transport of U-Th series radioisotopes from solids into ground water, Geochim. Cosmochim. Ac., 48, 395-399, 1984.

Sasaki, T., Gunji, Y., and Okuda, T.: Radon emanation dependence on grain configuration, J. Nucl. Sci. Technol., 41, 10, 993-1002, 2004.

Sasaki, T., Gunji, Y., and Okuda, T.: Theoretical study of high radon emanation, J. Nucl. Sci. Technol., 42, 2, 242-249, 2005.

Sesana, L., Caprioli, E., and Marcazzan, G. M.: Long period study of outdoor radon concentration in Milan and correlation between its temporal variations and dispersion properties of atmsphere, J. Environ. Radioactiv., 65, 147-160, 2003.

Sun, H. and Semkow, T. M.: Mobilization of thorium, radium and radon radionuclides in ground water by successive alpha-recoils, J. Hydrol., 205, 126-136, 1998.

Swedjemark, G. A.: The history of radon from a Swedish perspective, Radiat. Prot. Dosim., 109, 4, 421-426, 2004.

WHO: Guidelines for Drinking-water Quality, Third Edition, World Health Organization, Geneva, 2004.

Wood, W. W., Kraemer, T. F., and Shapiro, A.: Radon $\left({ }^{222} \mathrm{Rn}\right)$ in ground water of fractured rocks: A diffusion/ion exchange model, Ground Water, 42, 4, 552-567, 2004.

Zuber, A., Weise, S. M., Osenbrück, K., Grabczak, J., and Ciężkowski, W.: Age and recharge area of thermal waters in Lądek Spa (Sudeten, Poland) deduced from environmental isotope and noble gas data, J. Hydrol., 167, 327-349, 1995. 